\title{
Indirect evaluation of estrogenic activity post heterotopic ovarian autograft in rats $^{1}$
}

\author{
Avaliação indireta da atividade estrogênica após transplante heterotópico de ovário em ratas
}

\author{
Luciana Lamarão Damous ${ }^{I}$, Sônia Maria da Silva ${ }^{\mathrm{II}}$, Ricardo dos Santos Simões ${ }^{\mathrm{III}}$, Célia Regina de Souza Bezerra Sakano ${ }^{\mathrm{IV}}$, \\ Manuel de Jesus Simõesv, Edna Frasson de Souza MonterovI \\ ${ }^{\text {I }}$ Fellow PhD Degree, Surgery and Research Post-Graduate Program, UNIFESP, São Paulo, Brazil. \\ ${ }^{\text {II }}$ Fellow Master Degree, Surgery and Research Post-Graduate Program, UNIFESP, São Paulo, Brazil. \\ III Assistant Doctor, Gynecological Division, São Paulo University, Brazil. \\ Iv MS, Citopathologist, Gynecological Division, UNIFESP, São Paulo, Brazil. \\ ${ }^{v}$ Full Professor, Histology and Structural Biology Division, Department of Morphology, UNIFESP, São Paulo, Brazil.

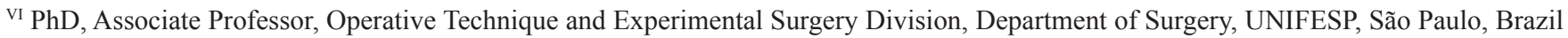

\begin{abstract}
Purpose: To morphologically evaluate the estrogenic effect on the uterus and vagina of rats submitted to ovarian autografts. Methods: Twenty Wistar EPM-1 adult rats were bilaterally ovariectomized, followed by ovarian transplants in retroperitoneal regions. The animals were divided in four groups of five animals, according to the day of euthanasia: G4, G7, G14 and G21, corresponding to the 4th, 7th, 14th and 21 st day after surgery, respectively. Vaginal smears were collected from the first day of surgery until euthanasia day. After that, the vagina and uterus were removed, fixed in 10\% formaldehyde and submitted to histological analysis and stained with hematoxiline and eosine. Results: All animals showed estrous cycle changes during the experiment. In 4th day, the uterus showed low action of estrogen with small number of mitosis and eosinophils as well as poor development. On the 7 th day, the endometrium was atrophic without mitotic signals and presented a small number of eosinophils. On the 14th and 21th days the histological findings were similar, with the presence of mitosis in the endometrial glands and intense leucocyte infiltration with a large number of eosinophils. Morphometric results showed that the endometrial and myometrial thickness as well as the number of eosinophils presented the highest values during the 14th and 21th days of the evaluation. The 7th day group also presented the lowest eosinophil numbers. Vaginal epithelium features were: 4th and 7th day groups presented non-keratinized stratified epithelium with 5 and 2 cell layers, respectively. The 14 th and 21 st day groups presented nonkeratinized stratified epithelium with 14 and 15 cell layers. Conclusion: Experimental ovarian autografts in the evaluated organs presented maximum estrogen activity after the 21 st day of surgery, according to morphological and morphometric data.
\end{abstract}

Key words: Transplantation. Ovary. Uterus. Vagina. Rats.

\section{RESUMO}

Objetivo: Avaliar morfologicamente a atividade estrogênica no útero e vagina de ratas submetidas a transplante autólogo de ovário. Métodos: Foram utilizadas 20 ratas adultas, Wistar EPM-1, submetidas à ooforectomia bilateral seguida de transplante de ovário em retroperitônio, distribuídas em grupos, conforme a data pré-estabelecida para eutanásia, com cinco animais cada: G4, G7, G14 e G21 - eutanásia no $4^{\circ}, 7^{\circ}, 14^{\circ}$ e $21^{\circ}$ dia de pós-operatório, respectivamente. No $1^{\circ}$ dia após a cirurgia foi iniciada coleta de esfregaço vaginal diariamente até o dia pré-estabelecido para eutanásia. Após a eutanásia foi realizada exérese em bloco da vagina e útero, que foram fixados em formol 10\% para processamento histológico e coloração pela Hematoxilina-Eosina. Resultados: Todos os animais mostraram alterações do ciclo estral no decorrer dos dias do experimento. No $4^{\circ}$ dia, o útero mostrava sinais de baixa atividade estrogênica, o endométrio apresentava poucas figuras de mitose, pouco desenvolvimento e pequena quantidade de eosinófilos. Já no $7^{\circ}$ dia, o endométrio encontrava-se atrofiado, sem atividade mitótica e com raros eosinófilos. No $14^{\circ}$ e $21^{\circ}$ dias os achados foram semelhantes, com presença de mitose nas glândulas endometriais e intenso infiltrado leucocitário, com predomínio de eosinófilos. Os resultados da morfometria mostraram que tanto as espessuras endometrial e miometrial quanto o número de eosinófilos foram maiores no $14^{\circ}$ e $21^{\circ}$ dias de avaliação, com menores valores no $7^{\circ}$ dia. As características do epitélio vaginal foram: epitélio pavimentoso não queratinizado no $4^{\circ}$ e $7^{\circ}$ (com cerca de cinco e duas camadas celulares, respectivamente) e pavimentoso queratinizado em no $14^{\circ}$ e $21^{\circ}$ dias (com cerca de 14 e 15 camadas celulares, respectivamente) Conclusão: $O$ transplante experimental autólogo de ovário manteve a atividade estrogênica nos órgãos avaliados, com atividade estrogênica máxima ao final de 21 dias, conforme parâmetros morfológicos e morfométricos.

Descritores: Transplante. Ovário. Útero. Vagina. Ratos.

${ }^{1}$ Research performed at the Surgery and Research Post-Graduate Program, Federal University of São Paulo (UNIFESP), Brazil. 


\section{Introduction}

Currently, ovarian transplantation is subject to intense scientific investigation, since pregnancy and labor after transplantation are fundamental for the good quality of life of patients subjected to cancer chemotherapy ${ }^{1}$.

The outcome of ovarian transplantation may vary, depending on the locus elected for grafting, on whether it is orthoor heterotopic, on its size (complete or sliced ovary), the type of preservation and the presence of vascular anastomosis, among other factors. The results depend on the number of viable ovarian follicles and on the time of graft survival, but all authors agree that a decrease in the number of follicles is due to previous ischemia of the graft $2,3,4,5$.

The growth of ovocites and follicles are impaired in many ways following events like ischemia and reperfusion which are installed in the setting up of the new blood supply to the newly transplanted tissue ${ }^{6,4}$. Efforts must, therefore, focus on new strategies that might improve this kind of graft, specially on the preservation of viable ovarian follicles, and the quality of the ovocites ${ }^{4,5}$.

The transplanted ovarian graft without vascular anastomosis produces a series of growth factors, like the vascular endothelial growth factor (VEGF), transforming growth factor beta $_{1}\left(\right.$ TGF- $\left.\beta_{1}\right)$, and gonadotropins which, in their turn, lead to angiogenesis in a relatively short, though critical, interval after graft transplantation $(48 \mathrm{~h})^{6}$. These stimuli seem to be triggered by hypoxia, mainly when the ovary is implanted on ectopic sites. The presence of antral follicles happens regardless of the implantation site of the ovarian tissue and hormonal stimulation with gonadotropins after the surgery, previously observing the hormone levels maintenance ${ }^{5}$.

Among the methods for indirect ovarian activity evaluation, the most used is the study of the vaginal smears of those animals, which shows this activity in a dynamic way?

Another parameter used in experimental studies is the evaluation of the shape and weight of the uterus ${ }^{2,8}$. In spite of the accepted sensibility of those methods; they are not very accurate in evaluating hypoestrogenic states, or in showing the alterations that may happen after transplantation.

Therefore, the objective of the present study is to evaluate the estrogenic activity on the uterus and vagina of rats subjected to heterotopic ovarian autograft.

\section{Methods}

The animals were housed and used upon approval (Protocol no. 1327/2006) of the Committee on Ethics and Research of the São Paulo Federal University (UNIFESP). Twenty virgin, adult (120-180 day-old, 200-300 g b.w) female Wistar EPM-1 rats were used. During the experimental period, the animals were fed with rat chow and water ad libitum.

The animals were weighed and anesthetized with ketamine $(70 \mathrm{mg} / \mathrm{Kg})$ and xylazine $(10 \mathrm{mg} / \mathrm{Kg})$, and were kept on natural room air breathing during all the procedures. Procedures were made under surgical microscope (DF Vasconcellos ${ }^{\circledR}$ ) set to a $10 \mathrm{X}$ magnification. After tricotomy and PVPI antisepsis, a medial laparotomy was made.

A bilateral exeresis of meso-ovarium was made using an 8-0 nylon suture thread. After being freed from any foreign tissue, the ovary which was to be transplanted was washed in physiological solution $(0.9 \% \mathrm{NaCl})$, just before transplantation. The contralateral ovary was histologically evaluated in order to be checked for any possible pathology.

After removal, cleaning and rinsing, the entire excised ovary was immediately placed into the retroperitonium without vascular anastomosis and fixed with simple 8-0 Prolene thread. The suture of the surgical wound was made in two layers: peritoneum-muscle-aponeurosis, and skin. Both sutures used a 5-0 monofilamentar nylon thread.

After transplantation, the animals were distributed into four groups of five animals each, namely G4, G7, G14 and G21, which were euthanized by excess anesthesia on the 4th, 7th, 14 th and 21 st day after operation, respectively.

Vaginal smears were collected once daily, starting on the first post-operative day; the last sample was obtained on the day before euthanasia. A swab soaked in physiological solution was used; the material was placed on conventional slides and immediately fixed in alcohol and colored, using the Shorr-Harris technique.

Under surgical anesthesia, vagina and uterus were removed and immediately fixed in $10 \%$ formaldehyde. Routine histological processes were employed for paraffin inclusion, sectioning and hematoxyline-eosine staining.

The thickness of the endometrium, miometrium and vaginal epithelium was evaluated; the presence of leukocytes in the endometrium was also quantified. Appropriate image capture was made using a light microscope (Axiolab Standart 20, Carl Zeiss, Jena, Germany) coupled to a video camera (AxionCam, Carl Zeiss, Jena, Germany). Measurement was carried out with image analysis software (AxionVision 4.2 REL Carl Zeiss, Jena, Germany). Leukocytes were counted in a total area of $35 \mathrm{~mm}^{2}$ of each animal.

Data are expressed as mean $\pm \mathrm{SD}$ and analyzed by ANOVA. Whenever appropriate, the Tukey-Kramer test for multiple comparisons was used. $P$ values $<0.05$ were considered statistically significant.

\section{Results}

\section{Citology}

All animals showed an altered estrous cycle during the experimental period. In the G4 and G7 groups, the estrous cycle was irregular predominating the diestrous phase with few observable cells. G4 presented some cells from the superficial layers and G7 a high percentage of basal cells could be seen, besides mucus and numerous neuthophils. In G4 and G21 a more regular estrous cycle was detected; at the end of the experiment the animals were all at estrus. 


\section{Uterus}

In $\mathrm{G} 4$ the uterus was lined with a simple cylindrical epithelium; the endometrium contained some eosinophils and euchromatin-rich fibroblasts (Figures $1 \mathrm{~A}$ and 2A). In G7 the uterus was somewhat atrophic and lined with cubic-to-cylindric epithelium; the endometrium contained a very high number of fibroblasts presenting small or picnotic nuclei (Figures 1B and 2B). In G14 and G21 the uterus was well developed, with a simple cylindrical epithelium lining and fibroblast-rich propria laminae with a high number of eosinophils (Figures 1C, 1D, 2C and D).

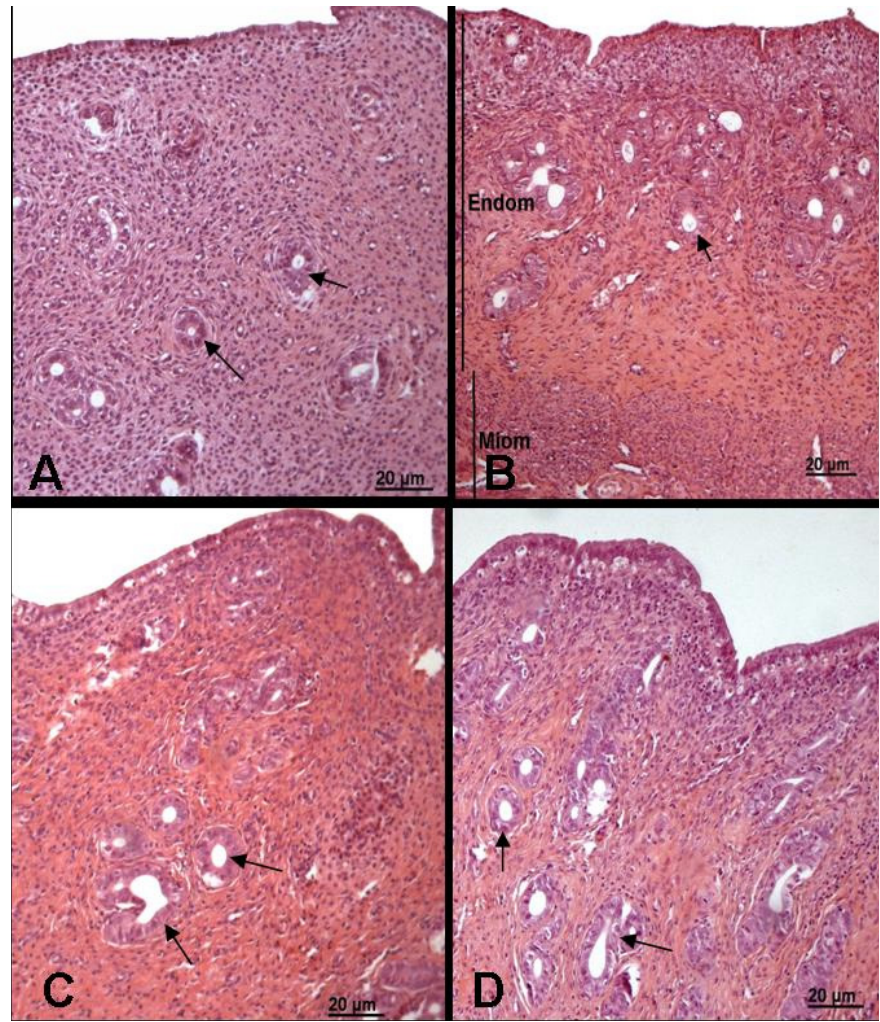

FIGURE 1 - Photomicrography showing representative uterus of rats: $\mathrm{A}=\mathrm{G} 4, \mathrm{~B}=\mathrm{G} 7, \mathrm{C}=\mathrm{G} 14$ and $\mathrm{D}=\mathrm{G} 21$. In A, presence of some endometrial glands (arrows); in $\mathrm{B}$ all the endometrial extension (Endom) and the miometrium (Miom) are seen. In C and D the endometrium appears well developed with a high content of endometrial glands. H.E (200X)
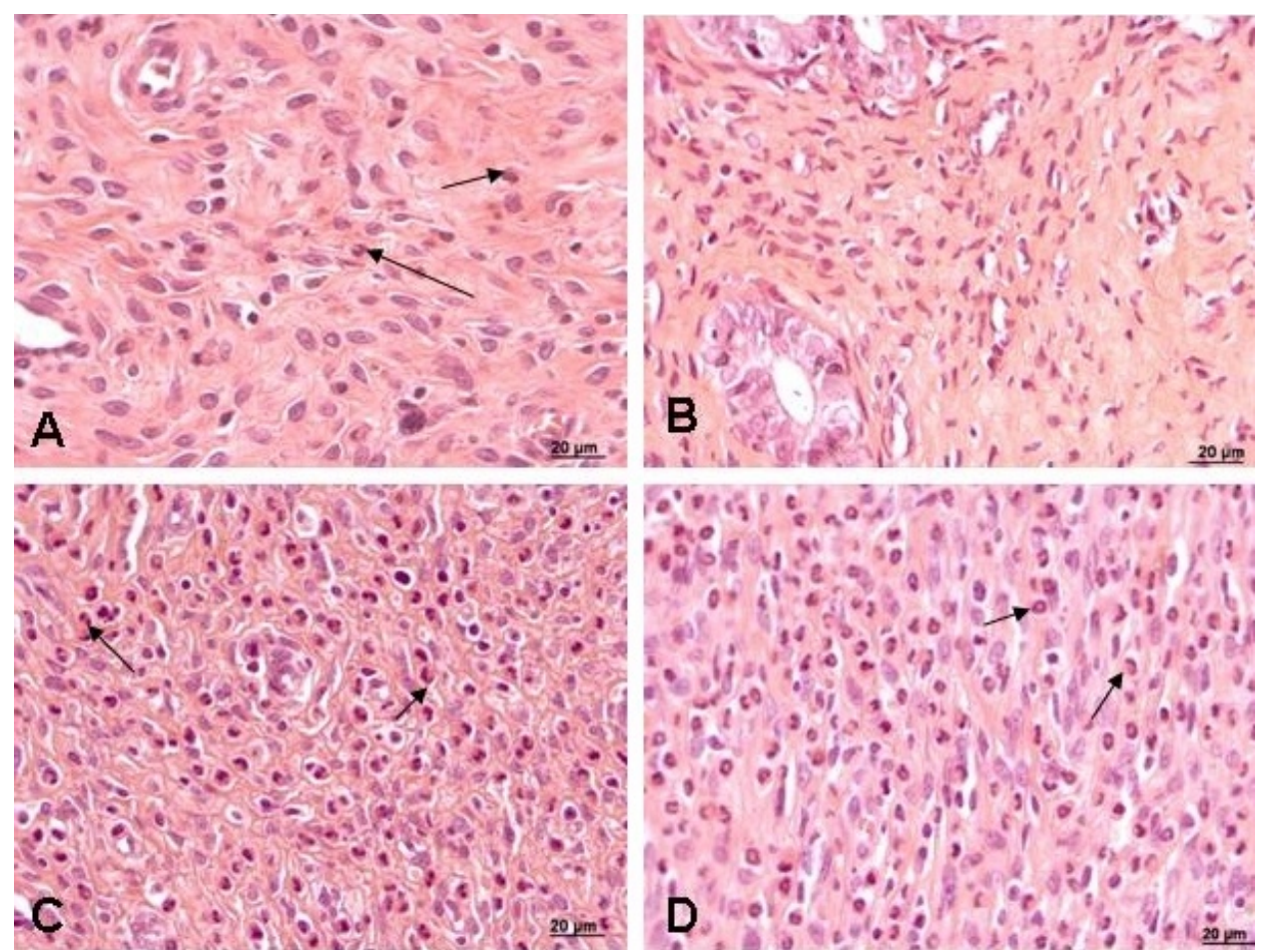

FIGURE 2 - Photomicrographs of rat endometrium (groupings are as in the legend of Figure. 1). Notice that in A there are some leukocytes (arrows), which are fewer in B. Leukocyte number was dramatically increased in C and D. H.E. (400X) 
Vagina

In $\mathrm{G} 4$, the vagina was lined with a 3-4 cell layer of non-keratinized, stratified squamous epithelium. The lamina propria was constituted of dense connective tissue, rich in cells and blood vessels, and the presence of some leukocytes was noticed permeating the epithelial tissue (Figure 3A). In G7, there was a remarkable reduction of the epithelial tissue thickness, which was then constituted of two cell layers and a lamina propria rich in collagen fibers (Figure 3B). Vaginal morphology in G14 and G21 was well developed; in G14 there was a lining of stratified squamous epithelium, formed by 10-12 cell layers (Figure 3C). In G21 this epithelium was keratinized with 1416 layers. In both cases, the lamina propria was formed by cellrich connective tissue (Figure 3D).

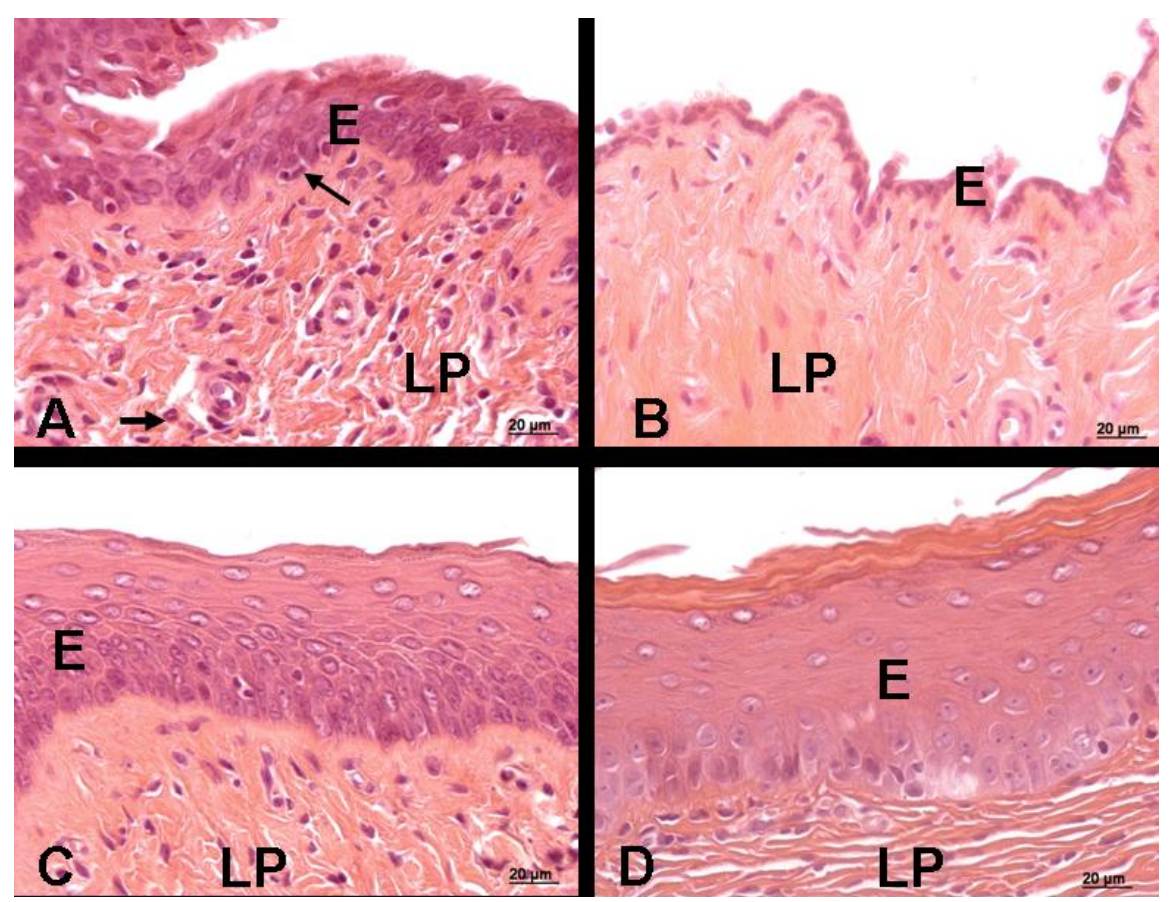

FIGURE 3 - Photomicrography showing rat vagina sections (groupings are as in the legend of Figure 1). In A, notice the stratified squamous epithelium (E) and the lamina propria (LP) rich in cells with small leukocyte infiltration (arrows). In B there is a thin epithelium (E) and a collagen-rich lamina propria (LP). In C, the stratified epithelium (E) appears to be thick and in D a squamous stratified epithelium is seen (E). H.E. (400X)

Morphometry

TABLE 1 - Thickness (mean \pm SD) of rat endometrium, miometrium and vaginal epithelium, and number of leukocytes in the endometrium of rats in G4, G7, G14 or G21

\begin{tabular}{lcccc}
\hline & \multicolumn{3}{c}{ GROUPS } \\
\cline { 2 - 5 } & $\mathbf{G 4}(\mathbf{n}=\mathbf{5})$ & $\mathbf{G 7}(\mathbf{n}=\mathbf{5})$ & $\mathbf{G 1 4}(\mathbf{n}=\mathbf{5})$ & $\mathbf{G 2 1}(\mathbf{n}=\mathbf{5})$ \\
\hline $\begin{array}{l}\text { Endometrium } \\
(\mu \mathbf{m})\end{array}$ & $380.7 \pm 102.3$ & $195.3 \pm 47.6$ & $510.4 \pm 49.7$ & $565.8 \pm 57.00$ \\
$\begin{array}{l}\text { Myometrium } \\
(\mu \mathbf{m})\end{array}$ & $343.8 \pm 27.7$ & $128.9 \pm 12.6$ & $322.7 \pm 39.2$ & $360.1 \pm 30.2$ \\
$\begin{array}{l}\text { Vaginal epithelium } \\
(\mu \mathbf{m})\end{array}$ & $71.0 \pm 11.0$ & $34.5 \pm 8.6$ & $107.9 \pm 12.1$ & $121.6 \pm 5.5$ \\
$\begin{array}{l}\text { Eosinophils } \\
(\text { cells/mm }\end{array}$ & $14.2 \pm 3.0$ & $0.4 \pm 0.03$ & $32.8 \pm 2.8$ & $34.2 \pm 4.8$ \\
\hline
\end{tabular}

Eosinophils in the endometrium: p<0.001 G4 x G7, G4 x G14, G4 x G21, G7 x G14, G7 x G21; p>0.05 G14 x G21. Vaginal epithelium: $\mathrm{p}<0.01 \mathrm{G} 4$ x G7, G4 x G14, G4 x G21; p<0.001 G7 x G14, G7 x G21; p >0.05 G14 x G21; Endometrium thickness: $<<0.001$ G4 x G7, G4 x G14, G4 x G21, G7 x G14, G7 x G21; p>0.05 G14 x G21. Myometrium thickness: p<0.001 G4 x G7, G4 x G14, G4 x G21; p >0.05 G4 x G14 x G21. 


\section{Discussion}

It was apparent that cryopreservation did not interfere with the graft follicle quality or even with the fertility after transplant, since the rates of follicle growth were similar, even to those of the primordial and transitory follicle, either in transplants of fresh or cryopreserved tissue ${ }^{1}$. Although many aspects have been investigated about the viability of those follicles, our knowledge about its repercussion on the female's genitalia, especially on the uterus and vagina, is still fragmentary.

In the present study, the morphologic and morphometric data revealed that the vagina had an important atrophy in G4 and G7, whereas in the uterus such a finding was evident only in G7.

Uterine proliferation was maintained in G4, although in small proportion when compared with other times (G14 and $\mathrm{G} 21$ ). It is conceivable that this occurred due to the action of reminiscent hormones, which were produced before the procedure or originated in non-ovarian sites. Such reminiscent hormones were not capable to maintain the thickness of the vaginal epithelium, already atrophied in the first two groups of euthanasia (G4 and G7). This could mean that the vagina of female rats is more liable to hormonal variations than the uterus, which in its turn is rich in hormonal receptors and compensatory mechanisms.

The response of the female rat uterus to estrogenic stimuli can be divided into two phases: an early phase ( $6 \mathrm{~h}$ after exposition) and a late (6-36 h after exposition). In the early phase, the responses consist of vascular permeability alterations, hydric absorption and cell infiltration. Many of those early changes closely resemble an inflammatory response and can be regulated by inflammatory mediators secreted by the uterus, namely histamine, serotonin and others; whereas it is believed that the late response is mediated by genomic factors 9 .

In this context, von Eye Corleta et al. ${ }^{8}$ evaluated, during a 3-week period, the vaginal smear cytology and the uterus weight, after ovary subcutaneous transplantation without vascular anastomosis, and observed that this technique preserved the endocrine functions of the transplanted tissue.

In agreement with Callejo et al. ${ }^{10}$, the analysis of rat weight gain is a doubtful parameter for hypoestrogenism, since the increase of body mass index can happen due to a secondary source of estrogen, for example, the peripheral conversion of fat tissue by aromatase. This way, those authors suggest that FSH blood and estradiol levels should be used as trustful markers of graft function.

In the uterus, the results showed evidences of estrogen action: increase in endometrial and miometrial thickness as well as the high number of eosinophils. This last parameter has direct relation to estrogenic effect on this organ. In immature and pregnant rats, uterine infiltration with eosinophils is smaller than in mature animals; infiltration varies even during the estrous cycle, being more intense during estrus ${ }^{11}$.

Oktay et al. ${ }^{2}$ evaluated the vaginal introitus, the uterus shape and estradiol levels in xenotransplants. They observed that the genitalia showed evidences of estrogen effects even during the absence of antral follicle growth, once the rodent genital tract responds to low levels of sex steroids. This could imply that, in the present study, the hormonal levels until the 7 th day were low enough to allow progressive uterine and vaginal atrophy, the remission occurring on the 14th and 21 st days after the procedure.

It is important to emphasize that the morphologic and morphometric data had a direct correlation to hormonal levels as observed by Oktay et al. $^{2}$ and Callejo ${ }^{3,10}$. In our experiment, there was a decrease in ovary activity in G4, reaching its lowest value in G7 (elevated levels of FSH and reduced estradiol levels), its activity started to recover in G14, and the function was fully restored after 21 days of the transplant.

Currently, transplant procedures include several strategies to maintain the female reproductive functions, such as the cryopreservation of mature or immature oocytes, of embryos and of ovarian tissue, being the latter a possible alternative for patients who need immediate chemotherapy. This way, the implant of ovarian cortex tissue in diverse sites after chemotherapy can be made ${ }^{12}$.

Intact and fresh ovary transplant have been successfully used in rats, rabbits, sheep, dogs and humans, independent of the implantation site. The loci most used have been the subcutaneous space, the renal capsule and the abdominal cavity, all subjected to temperature and pressure influence ${ }^{12,13,14}$.

It is believed that the best place for ovary implantation is at close proximity to an important blood vessel like the renal or the femoral artery; accordingly, the subcutaneous site can be viewed to be the worst place in terms of blood supply to the follicle ${ }^{4}$. Notwithstanding, the results are similar, as far as hormonal levels and vaginal cytology are concerned, when the implant is intra-peritoneal or subcutaneous ${ }^{15}$.

Although transplanted ovaries become revascularized and reenervated, the transplantation procedure, with its inherent ischemia/reperfusion insult, alters not only the process of follicle growth itself, but also the organ morphology. As a consequence, there are different degrees of parenchymatous fibrosis and compensatory hyperplasia of the cell layer in a short and long-term ${ }^{3}$.

The critical time for the full recovery of ovarian function after transplant happens during the first $24 \mathrm{~h}$, when there is a response to the ischemia/reperfusion insult that is the main factor responsible for alterations due to this procedure that finishes with angiogenesis and revascularization. Although the activation of angiogeneic factors in transplanted ovaries is stimulated by hypoxia, the transient increase of gonadotrofins in the immediate post-surgical period also contributes to the revascularization process ${ }^{6}$.

Further studies of those organs are necessary, with similar analysis of what was already seen on the transplanted ovarian parenchyma, which shows and increase in angiogenic factors like VEGF and TGF, besides apoptosis levels of cellular proliferation characterization. 


\section{Conclusion}

Experimental ovarian autograft, under the conditions established for this experiment, maintained ovarian activity in genital organs. Signs of hipoestrogenism from the 7 th day after operation, with maximum estrogenic activity to the end of the 21 st day, as judged by morphologic and morphometric data were observed.

\section{References}

1. Gunasena KT, Lakey JRT, Villines PM, Critser ES, Critser JK. Allogeneic and xenogeneic transplantation of cryopreserved ovarian tissue to athymic mice. Biol Reprod. 1997;57(2):226-31.

2. Oktay K, Newton H, Gosden R. Transplantation of cryopreserved human ovarian tissue results in follicle growth initiation in SCID mice. Fertil Steril. 2000;73(3):599-603.

3. Callejo J, Vilaseca S, Medina M, Salvador C, Valls C, Lailla JM. Inhibin and follicular development in heterotopical ovary transplants without vascular pedicle in syngeneic Lewis rats. Fertil Steril. 2003;79 Suppl 1:743-8.

4. Israely T, Dafni H, Granot D, Nevo N, Tsafriri A, Neeman M. Vascular remodeling and angiogenesis in ectopic ovarian transplants: a crucial role of pericytes and vascular smooth muscle cells in maintenance of ovarian grafts. Biol Reprod. 2003;68(6):2055-64.

5. Yang HY, Cox S, Jenkin G, Findlay J, Trounson A, Shaw J. Graft site and gonadotrophin stimulation influences the number and quality of oocytes from murine ovarian tissue grafts. Reprod Res. 2006;131:851-9.
6. Dissen GA, Lara HE, Fahrenbach WH, Costa ME, Ojeda SR. Immature rat ovaries become revascularized rapidly after autotransplantation and show a gonadotropin-dependent increase in angiogenic factor gene expression. Endocrinology. 1994;134(3):1146-54.

7. Marcondes FK, Bianchi FJ, Tanno AP. Determination of the estrous cycle phases of rats: some helpful considerations. Braz J Biol. 2002;62(4A):609-14.

8. Corleta HE, Corleta O, Capp E, Edelweiss ME. Subcutaneous autologous ovarian transplantation in Wistar rats maintains hormone secretion. Fertil Steril. 1998;70(1):16-9.

9. Kamat BR, Isaacson PG. The immunocytochemical distribution of leukocytic subpopulations in human endometrium. Arch Pathol.1987;127:66-73.

10. Callejo J, Vilaseca S, Ordi J, Cabré S, Lailla JM, Balasch J. Heterotopic ovarian transplantation without vascular pedicle in syngeneic Lewis rats: long-term evaluation of effects on ovarian structure and function. Fertil Steril. 2002;77(2):396-402.

11. Ross R, Klebanoff SJ. The eosinophilic leukocyte. J Exp Med. 1966;124:653-9.

12. Donnez J, Martinez-Madrid B, Jadoul P, Langendonckt AV, Demylle D, Dolmans MM. Ovarian tissue cryopreservation and transplantation: a review. Hum Reprod Update. 2006;12(5):519-35.

13. Torrents E, Boiso I, Barri PN, Veiga A. Applications of ovarian tissue transplantation in experimental biology and medicine. Hum Reprod Update. 2003;9(5):471-81.

14. Oktay K, Karlikaya GG, Aydin BA. Ovarian cryopreservation and transplantation: basic aspects. Mol Cell Endocrinol. 2000;169:105-8. 15. Callejo J, Jáuregui MT, Valls C, Fernandez ME, Cabré S, Lailla JM. Heterotopic ovarian transplantation without vascular pedicle in syngeneic Lewis rats: six-month control os estradiol and follicle-stimulating hormone concentrations after intraperitoneal and subcutaneous implants. Fertil Steril. 1999;72(3):513-7.

Conflict of interest: none Financial source: FAPESP

\section{Correspondence:}

Edna Frasson de Souza Montero

Alameda Espada, 134/11

06540-395 Santana de Parnaíba - SP Brazil

Phone: (5511)5549-7495

edna.montero@gmail.com

Received: January 18, 2008

Review: February 14, 2008

Accepted: April 16, 2008

\section{How to cite this article}

Damous LL, Silva SM, Simões RS, Sakano CRSB, Simões MJ, Montero EFS. Indirect evaluation of estrogenic activity post heterotopic ovarian autograft in rats. Acta Cir Bras. [serial on the Internet] 2008 July-Aug;23(4). Available from URL: http:// www.scielo.br/acb

*Color figures available from www.scielo.br/acb 